Anak Agung Banyu Perwita,1Ircha Tri Meilisa2 | Co-Operative Maritime Diplomacy: The Resolution Of The Philippines-Indonesia Maritime Border Dispute (1994-2014)

\title{
Article \\ Co-Operative Maritime Diplomacy: The Resolution Of The Philippines-Indonesia Maritime Border Dispute (1994-2014)
}

\author{
Anak Agung Banyu Perwita, ${ }^{1}$ Ircha Tri Meilisa ${ }^{2}$ \\ ${ }^{1}$ International Relations Departement,School of International Relations President University, Indonesia \\ ${ }^{2}$ International Relations Departement,School of International Relations President University, Indonesia
}

\section{SUBMISSION TRACK}

$\begin{array}{ll}\text { Recieved } & : \text { 13 March } 2018 \\ \text { Final Revision } & : \text { 13 September 2018 } \\ \text { Available Online } & : \text { 30 November } 2018\end{array}$

KEYWORD

Maritime Border Dispute, Co-operative Maritime Diplomacy, the Exclusive Economic Zone,

Common Interest, Foreign Policy

KATA KUNCI

Sengketa Perbatasan Maritim, Diplomasi

Kerjasama Maritim, Zona ekonomi eksklusif,

Kepentingan bersana, kebijakan luar negeri

\section{CORRESSPONDENCE}

Phone : 08122044951

E-mail : aabanyu.perwita@gmail.com

\section{A B S T R A C T}

This article aims to analyze the Philippines-Indonesia maritime border dispute in the Exclusive Economic Zone from Celebes to Mindanao sea. Using the neoliberalism perspective, the authors analyzed the interest of the Philippines to establish cooperation with Indonesia related to the national territory of each country, each legislation, maritime zones, and exercise of sovereignty over disputes maritime territories. Meanwhile, co-operative maritime diplomacy also used to determine the Philippines action in the form of bilateral cooperation, joint exercise on maritime security and regional cooperation to secure the Philippines and Indonesia maritime areas. On behalf of common interest, both countries succeed in maintaining their relations to achieve mutual goals regardless of boundaries. Furthermore, the foreign policy theory will also play an intervening role to explain the regulation about the dispute settlement efforts of delimitation boundary between the Philippines and Indonesia.

\section{A B S T R A K}

Artikel ini bertujuan untuk menganalisis sengketa perbatasan maritim Filipina-Indonesia di Zona Ekonomi Eksklusif dari Celebes ke laut Mindanao. Menggunakan perspektif neoliberalisme, para penulis menganalisis kepentingan Filipina untuk menjalin kerjasama dengan Indonesia terkait dengan wilayah nasional masing-masing negara, masingmasing undang-undang, zona maritim, dan pelaksanaan kedaulatan atas sengketa wilayah maritim. Sementara itu, diplomasi maritim kooperatif juga digunakan untuk menentukan tindakan Filipina dalam bentuk kerjasama bilateral, latihan bersama tentang keamanan maritim dan kerjasama regional untuk mengamankan wilayah maritim Filipina dan Indonesia. Atas nama kepentingan bersama, kedua negara berhasil mempertahankan hubungan mereka untuk mencapai tujuan bersama tanpa menghiraukan batas. Selanjutnya, teori kebijakan luar negeri juga akan memainkan peran intervensi untuk menjelaskan peraturan tentang upaya penyelesaian sengketa batas pemisah antara Filipina dan Indonesia. 
Anak Agung Banyu Perwita,1Ircha Tri Meilisa2 | Co-Operative Maritime Diplomacy: The Resolution Of The Philippines-Indonesia Maritime Border Dispute (1994-2014)

\section{Introduction}

The Philippines is one of the archipelagic countries in the world with more than 7,100 islands in the South China Sea. It lies off the coast of Southeast Asia, surrounded around the Pacific ocean, Celebes sea, Bornean waters and South China sea. The Philippines argued that its territorial limits described in accordance with the Treaty of Paris 1898 which define the archipelago of the Philippines shown up in the form of vast rectangle, with the size 600 miles in width and 1200 miles in length. ${ }^{128}$

Recognized as one of the founding fathers of the Association of Southeast Asian Nations (ASEAN), the Philippines actively plays its role to achieve ASEAN's regional agenda and maintain the significance of ASEAN in the international affairs. In its relations with ASEAN member states, the Philippines always seeks to strengthen its relationship on behalf of national priorities, particularly in security matters, which can pose a threat to regional stability. For instance, the Philippines embraced the ASEAN Declaration in the South China Sea in 1992, which guides the country to manage all sovereignty and jurisdiction issues, particularly in the South China Sea dispute to seek a peaceful resolution by promoting safer Southeast Asia, stable and free, in the form of initiatives in terms economic, trade and functional cooperation activities among the member states. ${ }^{129}$

128 Lowell Bautista, "The Philippines Treaty Limits and Territorial Water Claim In International Law" 5, no. 1/2 (n.d.): 107-27.

${ }^{129}$ “'The Philippines' Relationship With ASEAN - ASEAN Business News," accessed March 12, 2018,

https://www.aseanbriefing.com/news/2017/03/2

2/philippines-relationship-asean.html.
Reflected by the geographical condition, the Philippines and Indonesia considered as the largest and the most potential archipelagic countries in the World. Both countries also constituted as the official party of the United Nations Convention on the Law of the Sea (UNCLOS) 1982. Although both countries ratify at different time, the importance of the UNCLOS cannot be denied, especially for the Philippines as the first country who advocate the concept of archipelagic state in the world.

This article discusses the the Philippines-Indonesia maritime border dispute in the Exclusive Economic Zone from Celebes to Mindanao sea. Using the neoliberalism perspective, this article analyzed the interests of the Philippines to establish maritime border cooperation with Indonesia. Meanwhile, co-operative maritime diplomacy also used to determine the Philippines action in the form of bilateral cooperation, joint exercise on maritime security and regional cooperation to secure the Philippines and Indonesia maritime areas. On behalf of common interest, both countries succeed in maintaining their relations to achieve mutual goals regardless of boundaries. Furthermore, the foreign policy theory will also play an intervening role to explain the regulation about the dispute settlement efforts of delimitation boundary between the Philippines and Indonesia.

\section{Result and Disscusion}

\section{Maritime Border Disputes:between Philippines and Indonesia: The Highlight}

Historically, the Philippines and Indonesia have experienced Western colony for centuries. Indonesia experienced the Dutch colony for more than three hundred years, while the Philippines was colonized 
Anak Agung Banyu Perwita,1Ircha Tri Meilisa2 | Co-Operative Maritime Diplomacy: The Resolution Of The Philippines-Indonesia Maritime Border Dispute (1994-2014)

by the Spanish colony. However, the Philippines gained its independent in the end the Spanish-American, when Spain surrendered its power over the Philippine archipelago to the United State and left the country with unclear territorial boundary. At that time, Spain was calling all the remaining of its empire to sign the Treaty of Paris, which ceded the archipelago to the U.S and transferred the sovereignty of the Philippines. For this reason, the Philippines claims its current territorial boundaries on the basis of three treaties, which are the Treaty of Paris 1898, the Treaty of Washington 1900, and the Treaty concluded 1930. Nonetheless, these treaty limits are debated in the international law, it keeps running against the principles constituted under the article 56 and 57 of the UNCLOS. ${ }^{130}$ (See the figure I below)

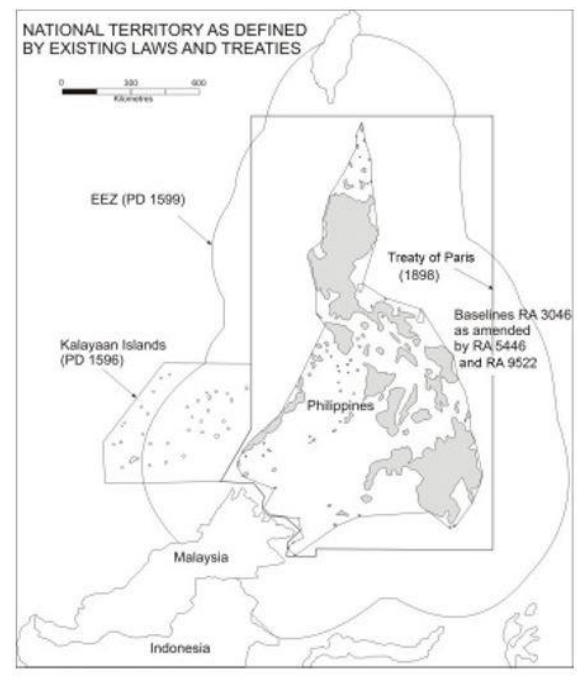

Figure I The Philippines Territory Based on The Philippines Treaty Limits (Source: The philippines treaty limits and territorial waters claim in international law)

The figure $I$ above, shows the territory of the Philippines based on based

\footnotetext{
${ }^{130}$ Bautista, "The Philippines Treaty Limits and Territorial Water Claim In International Law."
}

on the article 3 and of the Treaty of Paris 1898. However, this baseline law did not obey the provisions constituted in the UNCLOS, consequently, no country recognizes it. ${ }^{131}$ As the result, these treaty limits cause an overlapping maritime boundary in the Exclusive Economic Zone (EEZ) from Celebes to Mindanao sea which in some parts belong to Indonesia as well. (See Figure II below)

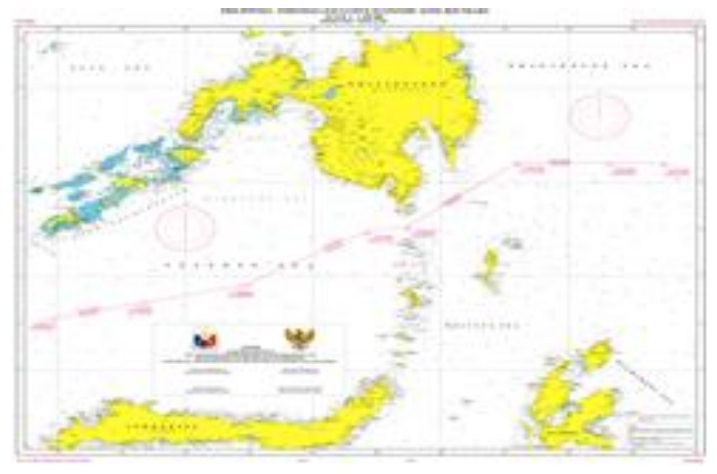

Figure II The Philippines-Indonesia EEZ Boundary (Source: Official Website of the DFA of the Philippines)

The overlapping EEZ area between the Philippines and Indonesia extends from the Celebes sea to Mindanao sea . Beyond just the matter of territorial borders, EEZ also plays a significant role in realizing the eco nomies of both countries as an archipelagic country whose livelihoods depend largely on the sea such as fisheries and natural gas reserves. Moreover, this area as the main route of International Shipping Lanes (ISL) where this area is passed by other countries for goods delivery activities. In scientific goals, EEZ lessons include the implementation of scientific research on a variety of marine creatures, and seabed sampling for oil and gas purposes that can also be carried out therein. ${ }^{132}$

\footnotetext{
131 ibid

132 "Philippines Coastal and Marine Resources: An Introduction" (The World Bank, n.d.), http://siteresources.worldbank.org.
} 
Anak Agung Banyu Perwita,1Ircha Tri Meilisa2 | Co-Operative Maritime Diplomacy: The Resolution Of The Philippines-Indonesia Maritime Border Dispute (1994-2014)

Maritime border dispute which claims over sea territory is concerned to control the capacity of a state towards resources management, sovereignty, security and national integrity. These factors could lead to unstable situations that unsettle interstate relations such as it will lead to overlapping and conflicts of sovereignty, for example, insecurity of the necessary rights, conflicting claims, and uncertainties regarding regulatory authority and inequalities in resource management or worst is armed conflict. Maritime border dispute requires legal clarity of territorial border between claimant states in order to achieve clearly defined boundary where a state hold a full authority of the area.

According to the law of the sea convention, every coastal state has "jurisdiction, rights and duties with regard to the establishment and use of artificial islands, installations and structures, marine scientific research and protection and preservation of the marine environment". ${ }^{133}$ Reflect on the previous statement, maritime border dispute might also contribute a negative effect for economic development, as public entities and private parties are unable to explore the resources of a disputed area because hard to determine what the activities are permitted without a legally defined boundary within the area.

Maritime boundary is beyond just boundary, it is all about demarcating with some degree of precision the area of the waters over which a State exercises effective sovereign control. Such boundary takes on a more crucial and important role in the international order when one considers the fact that it is in effect a boundary between the coastal State and of the interests of the

133 "The United Nations Convention on the Law of the Sea," n.d rest of the world. Realizing the maritime boundaries are essential and necessary parts of the international system, the Philippines and Indonesia managed a number of meetings to reach their final agreement of the delimitation of the EEZ boundary in accordance with the principle of UNCLOS.

As geographically, politically, and legally archipelagic countries, Indonesia and the Philippines have been confronted by several factors to immediately finalize each maritime boundary. The geographic position of both countries marked as maritime areas that often traversed by several kinds of vessels such as military vessels, including submarines and other nuclear powered vessels. ${ }^{134}$ Still, the areas also crossed by international aviation, both commercial and military. Accordingly, both countries realize those strategic geographical positions create significant benefits for their economic, political and security interest, thus, both become sensitive towards their maritime border. Hence, this paper is an exploration of The Implementation of the Philippines Maritime Diplomacy In Resolving the 20 Years of the Maritime Border Dispute on the overlapping EEZ boundary with Indonesia. Specifically, it seeks the answer the question on, how did the Philippines implement its maritime diplomacy to resolve maritime border dispute with Indonesia (1994-2014). The main focus of this paper is to explain the process of negotiation between the Philippines and Indonesia until the two countries finally reached their final agreement in 2014.

\section{The Beginning of the Philippines- Indonesia Negotiation on Maritime Border Dispute (1994-2001)}

\footnotetext{
134 Harry Purwanto and Dewa Gede Mangku, "Legal Instrument of the Republic of Indonesia on Border Management Using the Perspective of Archipelagic State" 11, no. 4 (n.d.): 56.
} 
Anak Agung Banyu Perwita,1Ircha Tri Meilisa2 | Co-Operative Maritime Diplomacy: The Resolution Of The Philippines-Indonesia Maritime Border Dispute (1994-2014)

The Philippines orientation on foreign policy in the early 1990s was dominated by the contradiction between subjective nationalism and objective dependency, especially due to the previous regime which inherent a volatile economic growth had pushed the Philippines to seek a more balanced foreign policy and retrieve the unstable economic, cultural, military and personal ties that close with the western influence specifically the US. ${ }^{135}$

Since the restoration of democracy, the Philippines under the Ramos administration was busy to breaking out the Philippine's status as "A Sick Man of Asia". During this period, the Philippines faced political difficulties while most of other economies were growing greatly. Its domestic economy has turned down due to huge public debt rooted since Marcos administration, which resulted in government devoting over of its third revenues on servicing interest payment, domestic saving were low, coup attempts, a serious power shortage, and growth remain flat or even negative. The Philippines relied upon foreign capital robustly due to the persistent economic deficit they faced. ${ }^{136}$

Ramos commenced the development of diplomacy as his foreign policy thrust. In formulating foreign policy, Ramos focused on the development of security, defense and socio-political aspect. ${ }^{137}$ During his administration, the global changes gave the Philippines more space to improve the country's development process and its security. In terms of maritime affairs, the

135 Bernardo, Romeo L. (2008). The Political Economy of Reform during the Ramos Administration (1992-98). Retrieved from the Commission on Growth and Development website: http://siteresources.worldbank.org

${ }^{136}$ Ibid page 11

137 Office of the President of the Philippines. (1994). [Executive Order Nos. : 126 - 300]. Manila : Presidential Management Staff. dramatic changes in the international system allow the Philippines to expand its international linkages with the countries around the Asia-Pacific. ${ }^{138}$ For this reason, the Philippines began its negotiation with Indonesia regarding border disputes at the First Senior Official Meeting in 1994. The meeting led by the Department of Foreign Affairs (DFA) of the Philippines also prepared the position of the Philippines within negotiation of the maritime border dispute with Indonesia. The meeting further discussed about the overlapping EEZ boundary from Celebes to Mindanao sea and prepare the guidelines for the delimitation talks. $^{139}$

Other than starting negotiation with Indonesia on maritime border dispute, one of the highlights during Ramos's administration was the Expanding of the Coverage of the Cabinet Committee on the Law of the Sea and renaming it as the Cabinet Committee on Maritime Affairs which launched in 1994. The Committee and its functions include, the formulation of practical and viable policies to address the various concerns on maritime affairs and the implementation of the UNCLOS ${ }^{140}$. Furthermore, by taking into account the importance and contribution of the marine sector and the environment of the ocean for the nation and international security, thus in the same year, on 8 November 1994, the Philippines embraced a National Marine Policy (NMP) which focused on the implementation of the UNCLOS and international environmental treaties, specifically in the development and

\footnotetext{
${ }^{138}$ Ibid

${ }^{139}$ Philippines and Indonesia Sign Agreement on EEZ Boundary, 2014. Retrived from www. dfa.gov.ph

140 Office of the President of the Philippines. (1994). [Executive Order Nos. : 126 - 300]. Manila : Presidential Management Staff.
} 
Anak Agung Banyu Perwita,1Ircha Tri Meilisa2 | Co-Operative Maritime Diplomacy: The Resolution Of The Philippines-Indonesia Maritime Border Dispute (1994-2014)

management of marine resources. In the implementation of NMP, it is limited by the legislation of the new Fisheries Code that further reinforces the roles of local government units in coastal resource management. The NMP demonstrated the Philippines as an archipelagic country and prioritized the contribution of marine resources in economic growth. In the implementation, the NMP is flexible depending on the time and dynamic situation of the ocean.

During this period of time, the Philippines keep promoting peaceful coexistence and mutual respect with Indonesia, hence this negotiation demonstrated as the Philippines approach to solve maritime disputes in an amicable way. However, at the implementation level, Ramos administration failed to sustain the realization of these policies. While domestic reforms were underway, the government was busy projecting a good image of the Philippines in the global market. Similar things experienced by Indonesi as well. For the period 1994-1998, Indonesia was led by President Soeharto. During his administration,he was a land-mined oriented. The development of terrestrial areas takes precedence as the concern of Soeharto's policies is agrarian and food issues. This is contrasted with the previous administration under Soekarno's in which initiated the development of maritime forces. ${ }^{141}$

During the Soeharto's administration, Indonesia's relations with foreign countries viewed as generally moderate, regionally unstable and tend toward the West, particularly in term of official development assistance and private investment. As a

${ }^{141}$ Pengantar Soal Perkembangan Politik Luar Negeri Terutama Kerjasama Negara-Negara ASEAN. (n.d.). Kementerian Kelautan dan Perikanan Republik Indonesia page 9 founding member of the Nonaligned Movement in 1961, Indonesia still adopted independent and active foreign policy and kept its neutral position equidistant from the contentious Soviet Union and the US. ${ }^{142}$

Considering the strategic location of Indonesia, with access to the eastern entrance to the Indian Ocean, command of the Malacca and Sunda straits, the country has been well known with its vital role in the Asian security, hence, it demanded the greater roles and responsibilities from the Department of Marine Affairs and Fisheries. The Directorate General of Marine and Fishery Resources Control has improved coordination and cooperation with security forces and law enforcement at sea. ${ }^{143}$ However, the limited facilities and infrastructure and the number of supervisory personnel are still the main obstacle in achieving optimal supervision performance. ${ }^{144}$ Thus, the government at this time more concentrated on national development which resulted in the marine sector and international relations lacking sufficient attention by the government. This is one of the problems that decrease the effectiveness of the implementation the Philippines maritime diplomacy and required several years to resolve, because both countries were too busy handling their domestic problems.

The Philippines-Indonesia Cooperation on Maritime Security (2001-2005)

In order to explore the PhilippinesIndonesia security cooperation on maritime affairs, the author decided to pick neoliberalism theory as the dominant political ideology of the nineteenth century following the concept of the theory, namely interdependence and common interest to provide the understanding of the relations

\footnotetext{
${ }^{142}$ Ibid

${ }^{143}$ Ibid

${ }^{144}$ Ibid
} 
Anak Agung Banyu Perwita,1Ircha Tri Meilisa2 | Co-Operative Maritime Diplomacy: The Resolution Of The Philippines-Indonesia Maritime Border Dispute (1994-2014)

between the Philippines and Indonesia, particularly in terms of maritime affairs. ${ }^{145}$ According to the neoliberalism perspective, the Philippines and Indonesia have a common interest that allows them to build a cooperation in order to achieve mutual goals. Since the diplomatic ties established in 1949, the Philippines and Indonesia appreciate a solid relation among them. The historical background of both countries has been highlighting the most critical in Southeast Asia. Yet, both countries also founders of ASEAN, the member of nonalignment movement and APEC. ${ }^{146}$ Therefore, dependencies have raised among them as they share a common interest that makes them depend to each other in term of economic, political, and security. ${ }^{147}$ Thus, both countries realized, their close cooperation, particularly in maritime domain is vital.

Generally, the Philippines has two concerns in maritime security, first is national security, second security issues with regional impact as defined in the NMP 1994, below:

"State in which the
country's marine assets,
maritime practices,
territorial integrity, and
coastal peace and order

\footnotetext{
${ }^{145}$ Robert O. Keohanne, Joseph S. Nye. (1989). Power and Interdependence (2nd ed.). Harper Collins Publishers.

146 The Philippines Indonesia to Hold 6th on Joint Commission on Bilateral Relations. (n.d.). Retrieved from https://dfa.gov.ph/newsroom/dfareleasesupdate/2175-philippines-indonesia-holdsuccessful-bilateral-talks

${ }^{147}$ Nye, J. S. (2011). The Future of Power. New York: Public Affairs.
}

\section{are protected, conserved, preserved and enhanced". 148}

The Celebes Sea, which has been contested by the Philippines and Indonesia, is the only marine area that can be passed by submarines and supertankers, thus this area is crucial for energy commerce and world trade. ${ }^{149}$ Unfortunately, due to the absence of legal clarity within this region due to the unclear territorial boundary, ultimately making this area facing many challenges and threats. This area also provides a comfortable place for terrorist organizations, pirates and civilians move easily because there is no strict supervision from the government. Pirates have established forbidden activities long before terrorist organizations operated. Those threats have caused many victims, including international shipping companies, large multinational corporations, even local fishermen who lost their ships. ${ }^{150}$ These conditions potentially jeopardize the implementation of maritime security cooperation between the Philippines and Indonesia and affect the livelihoods of local communities. Seeing the dangers affecting this region, unilateral action by one of the countries will not be enough to eradicate all types of crime, therefore, there is a need for a common movement to form effective and synergies bilateral cooperation to maintain and manage the area. ${ }^{151}$ For this reason, the Philippines-Indonesia security cooperation around the Celebes sea is crucial for their own national security and trade. Furthermore, with the presence of clear jurisdictions in the region will enable

${ }^{148}$ Cabinet Committee on Maritime and Ocean Affairs, "National Marine Policy," (Foreign Service Institute: Manila, Philippines, 1994).

${ }^{149}$ S Febrica, Maritime Security and Indonesia: Cooperation, Interests and Strategies (Routledge, n.d.).

${ }^{150}$ Ger Teitler, "Piracy in Southeast Asia," Mare Center for Maritime Research, n.d.

${ }^{151}$ Ibid 
Anak Agung Banyu Perwita,1Ircha Tri Meilisa2 | Co-Operative Maritime Diplomacy: The Resolution Of The Philippines-Indonesia Maritime Border Dispute (1994-2014)

countries around the area to develop and implement regulations in order to prevent crime. Because of this, following the 9/11 tragedy and the Bali bombings on October 12, 2002, the Philippines and Indonesia finally agreed to engage in bilateral cooperation in terms of security to combat threats occurring around the Celebes sea. Within this security cooperation, Arroyo as the Philippines' President with Indonesia's President: Megawati arranged a prominent bilateral security cooperation where they can examine the establish an aggressive combined response to maritime piracy and extend cooperation among the nations' intelligence and security services.

The Philippines-Indonesia security cooperation began in 2005, when both countries approved a four-point agreement contained bilateral security cooperation. On 21 June 2005, both countries declared the joint cooperation and agreed to quell all forms of transnational crime and counter terrorism. Ever since, both countries, governments have taken a more serious cooperation with the signing of the agreement cooperation in the field of security through a Memorandum of Understanding between the police services signed on 18 November $2005 .{ }^{152}$

In the form of cooperation, both countries managed to perform its roles against one another. In addition, in conducting the cooperation, the two countries also conduct police training and develop police capacity of both countries. They also discussed the boundaries of the territorial waters that terrorists serve as the pathway for the entry of terrorists located in Indonesia and the Philippines. In addition to being the entry point of terrorism, the border

152 "Indonesia, Philippines Reach Four-Point Agreement.” BBC. June 22, 2005. of the two countries is also used as a weapon smuggling line and many criminal acts such as illegal fishing. ${ }^{153}$

\section{The Philippines-Indonesia Involved in Multilateral Cooperation to Protect Marine Biodiversity (2006-2007)}

The location of the EEZ of the Philippines and Indonesia reaches the Coral Triangle area which is at the crossroads with growing rapid economic growth and international trade. Nonetheless, the seaside and marine assets in the Coral Triangle areas are experiencing significant degradation, and are facing increasing threats due primarily to a rapidly growing population, pollution, unsustainable coastal development, over fishing and sustainable fishing practices and climate changes.

The President of Indonesia, Susilo Bambang Yudhoyono aware that the urgent need to address threats occurring around the Coral Triangle area, hence, he first initiated a partnership and engage the countries around the region include, Indonesia, Malaysia, Papua New Guinea, Philippines, the Solomon Islands and Timor-Leste) during the Convention on Biological Diversity (CBD) in Brazil 2006. The initiation received positive inputs from the six countries. Therefore, in the following year, the six countries agreed to involve in multilateral collaboration called CTI in 2007 to achieve the new trajectory that ensures the conservation and sustainable use in the coral triangle area. ${ }^{154}$ CTI basically is regional cooperation to the protect one of

153 Febrica, S. (2017). Maritime security and Indonesia: Cooperation, interests and strategies. Routledge. Page 76

${ }^{154}$ Coral Triangle Initiative on Coral Reefs, Fisheries and Food Security, issuing body. (2009). Regional plan of action: Coral Triangle Initiative on Coral Reefs, Fisheries and Food Security (CTI-CFF). Interim Regional CTI Secretariat 
Anak Agung Banyu Perwita,1Ircha Tri Meilisa2 | Co-Operative Maritime Diplomacy: The Resolution Of The Philippines-Indonesia Maritime Border Dispute (1994-2014)

the most biologically diverse and ecological the richest regions on earth and to sustain its extraordinary marine and coastal resources from harm such as food security issues, climate change and marine biodiversity. ${ }^{155}$ However, significant progress made during the 2nd Senior Officials Meeting 2007, where the 6 countries produced a key decision to adopt Manila draft of Regional CTI-CFF Plan of Action. ${ }^{156}$

Within the CTI, the Philippines and Indonesia reinforced their commitments to cooperate on maritime affairs and show a good example how to still cooperate on major initiative regardless maritime border dispute. Additionally, the CTI allowed both countries to share their common interest and achieve mutual goals. By taking into account their people live very much depends on marine sources, the CTI not also as their form of maritime security, but also one of the Philippines maritime diplomacy in ease its unresolved boundaries with Indonesia without the use of force.

\section{The Philippines-Indonesia Maritime Border Dispute Gains Momentum (2007- 2009)}

After the 2008 global crisis, the world sees the shifting balance between two major powers, the US and China, thus, the post condition of the global crisis trigger China in shaping its Chinese assertiveness. Nevertheless, China still cannot defeat the power of the US in terms of creating a comprehensive national power and perhaps the US will remain dominant in the future. As the US slowly decline, China utilized these conditions to spread its influence and

${ }^{155}$ CTI-CFF | Coral Triangle Initiative on Coral Reefs Fisheries and Food Security. (n.d.). Retrieved from http://www.coraltriangleinitiative.org/

156 Coasting of the National Plan of Actions (NPOA) of the Philippines. (2015). Retrieved from Coastal and Marine Resources Management in the Coral Triangle website: prepare itself to be more aggressive, especially when it comes to South China Sea Dispute as China declares that the South China Sea is its primary interest. In its assertive action, China has adopted "a defensive approach" by reinforcing its claims without fundamentally changing its policies, therefore, its rigidity is seen as a threat to other claimant states in the South China Sea dispute. ${ }^{157}$ Furthermore, China's aggressiveness is also identified from Chinese attitudes towards its claims such as "changes in the distribution of power, the rise of Chinese nationalism, and the leadership transition politics in which China actively seeks its interests, and acts boldly to achieve its objectives, even if it contradicts with other claimant states". ${ }^{158}$

China has declared its maritime claims against the Philippines with increasing freedom. This kind of assertive Chinese action, however, triggered other claimant states in the South China Sea dispute, particularly the Philippines to create more proactive efforts and actions in line with UNCLOS's presentation of maritime claims in 2009. ${ }^{159}$

During the reign of President Arroyo, the Philippines changed its foreign policy strategy in response toward Chinese assertiveness. In 2009, the Philippines finally decided to harmonize its baseline law in accordance with UNCLOS by launching Republic Act No.9522. This new baseline law defines the territorial boundary of the Philippines in which also explicitly included the Kalayaan Islands and Scarborough Shoal, a move that sparked violent protests

157 Turcsányi, R. Q. (2018). The Puzzle of Chinese Assertiveness. In Chinese assertiveness in the South China Sea: Power sources, domestic politics, and reactive foreign policy. Prague: Springer. Page 7

${ }^{158}$ Ibid

${ }^{159}$ Ibid page 6 
Anak Agung Banyu Perwita,1Ircha Tri Meilisa2 | Co-Operative Maritime Diplomacy: The Resolution Of The Philippines-Indonesia Maritime Border Dispute (1994-2014)

from China and even caused China canceled its official visit to the Philippines. With the alignment of laws on these territorial boundaries, the Philippines has gained recognition from the international community. In fact, one of the objectives of this Philippine step is to balance the strength of China after China's increasing politicomilitary assertiveness to continue its maritime claims and hesitations to sign a legally binding Code of Conduct (CoC) suggests that the settlement is driven by geopolitical imperatives. ${ }^{160}$

RA 9522 legally defines the Philippines territorial borders with the various zones of maritime jurisdiction specified in the UNCLOS. Thus, the Philippines defines its maritime boundary and its Exclusive Economic Zone, also claim some parts of the Spartlys and other rocks and shoals in the South China Sea, in accordance with the archipelagic base set by the UNCLOS. This Philippine law action, then implies that the Philippines provides EEZ claims from the archipelagic baseline on its main island, and extends the continental shelf claim to China's southern seas beyond the limit of its EEZ. ${ }^{161}$ As for the Philippines, China's recent aggressive behavior made serious pressure. Regardless of China's assertiveness, however, the Philippine strategy to align its maritime law with UNCLOS through RA 9522 affects its longstanding maritime border disputes with Indonesia. As the Philippines aligns UNCLOS, it ultimately facilitates negotiations with Indonesia because of the same laws they use. Finally, after 20 years

160 Kreuzer, P. (2016). A Comparison of Malaysian and Philippine Responses to China in the South China Sea. The Chinese Journal of International Politics, 9(3), 263. Retrieved from https://doi.org/10.1093/cjip/pow008 ${ }^{161}$ Ibid of negotiations, the process gained momentum after March 2011. ${ }^{162}$

The Philippines-Indonesia Joint Commission on Bilateral Cooperation (2011-2014)

The Philippines and Indonesia realize their close cooperation in maritime affairs are vital. Although both countries have not yet establish any agreement on their maritime border dispute during this period of time, both countries show their cooperativeness by agreeing to increase coordination on a number of maritime issues include, improving their negotiation on maritime boundary delimitation, bilateral cooperation in a various of filed and security cooperation in combating threats such IUU fishing, piracy and terrorist under the scope of the Philippine-Indonesia Joint Commission for Bilateral Cooperation (JCBC).

In 2011, the Philippines and Indonesia agreed to extend their bilateral cooperation in the field of security, defense and border cooperation, marine and fisheries as well as trade and investment. During the 5th Meeting of the Philippines-Indonesia JCBC in Manila on 13-14 December, both countries committed to continuously sinergize and invigorate bilateral relations through a comprhensive review and renewing the previous agreement and the ordered implementation of cooperation in various areas.

"This 5th JCBC Meeting is testament to the strong and abiding friendship between the Philippines and Indonesia. It follows the momentum set by President Benigno S. Aquino III's State Visit to Indonesia at the invitation of President Susilo Bambang Yudhoyono early

${ }^{162}$ Ibid 
Anak Agung Banyu Perwita,1Ircha Tri Meilisa2 | Co-Operative Maritime Diplomacy: The Resolution Of The Philippines-Indonesia Maritime Border Dispute (1994-2014)

this year. During that visit, he witnessed the signing of four

(4) new agreements, all envisioning closer technical and people-to-people ties" statement Albert F. Del Rosario as the Philippine' Secretary of Foreign Affairs ${ }^{163}$

Following the statement from Rosario, he leads the delegation of the Philippines when both the Philippines and Indonesia hold the 6th meeting of JCBC on February 24, 2014 in Jakarta, Indonesia to further discuss the matters in the areas of defense, security, trade and investment, agriculture, fisheries, education, maritime cooperation, and border cooperation, among others. The meeting also includes the signing of the Philippines-Indonesia Plan of Action for 2014-2016 and the Memorandum of Understanding (MOU) between the Republic of the Philippines and the Republic of Indonesia on Mandatory Consular Notification and Assistance. ${ }^{164}$

"Hopefully, the treaty will be signed by both countries' leaders during President Susilo Bambang Yudhoyono's visit to Manila in May", said Marty Natalegawa as the minister of foreign affairs of Indonesia. ${ }^{165}$

With more intensive cooperation between the Philippines and Indonesia, the two countries show their good intentions to

163 Philippines, Indonesia Hold Successful Bilateral Talks. (n.d.). Retrieved from https://dfa.gov.ph/newsroom/dfa-

releasesupdate/2175-philippines-indonesia-holdsuccessful-bilateral-talks

${ }^{164}$ Ibid

165 The Jakarta Post. (2014, February). RI, Philippines Set to Sign Boundary Treaty. Retrieved from http://www.thejakartapost.com/news maintain harmony in their relationship and commit themselves to resolving all sovereignty conflicts as equally and equitably as possible. ${ }^{166}$

\subsubsection{The Final Agreement Concerning the Delimitation of the Exclusive \\ Economic Zone (2014)}

The Philippines under the administration of President Aquino has demonstrated a Philippine Foreign Policy that is independent, principled, and based on the rule of law. As one of the Philippines top priorities, DFA of the Philippines designed foreign policy strategy which intensifying the Philippines advocacy for the primacy of the rule of law, including the UNCLOS and peaceful settlement of disputes. ${ }^{167}$ Regard from that, the Philippines under Aquino's administration took into account its long standing negotiation of the maritime border dispute since 1994 with Indonesia. Fortunately, Indonesia welcomed the Philippines offer to immediately settle their maritime border dispute warmly. During the state visit to Manila for the World Economic Forum on East Asia in 2014, Indonesia's President: SBY expressed his gratitude after signing the agreement with the Philippines. ${ }^{168}$

"This indeed is a model, a good example, that any disputes, including maritime

166 Ellis, J., Moore, J. N., Nordquist, M. H., \& University of Virginia. (2012). Maritime border diplomacy. Leiden: Martinus Nijhoff Publishers.

${ }^{167}$ A Principled Philippine Foreign Policy Under the Aquino Administration. (n.d.). Retrieved from

https://dfa.gov.ph/index.php/speeches/8517-aprincipled-philippine-foreign-policy-under-theaquino-administration

168 Anwar, D. F. (2014, February 4). Indonesia's foreign relations: policy shaped by the ideal of 'dynamic equilibrium'. Retrieved from http://www.eastasiaforum.org 
Anak Agung Banyu Perwita,1Ircha Tri Meilisa2 | Co-Operative Maritime Diplomacy: The Resolution Of The Philippines-Indonesia Maritime Border Dispute (1994-2014)

border tension can be resolved peacefully - not with the use of military might which may endanger stability and peace in our region,".

Neither with the government of President Susilo Bambang Yudhoyono in Indonesia. Given the principle of "A million friends, zero enemy" for its foreign policy, means that Indonesia's foreign policy is more into soft diplomacy and changed the way of view to countries in Southeast Asia constructively where opponents become friends, and friends become strategic partners of Indonesia. Indonesia feels neither hostile to any country, nor hostile to any country so that Indonesia can do all foreign policy. ${ }^{169}$

In February 2014, the Philippines and Indonesia through each representative reviewing the overall bilateral relations between both countries by conducting the 6th Meeting of the Philippines-Indonesia Joint Commission on Bilateral Cooperation (JCBC) to discuss about bilateral cooperation of both countries in terms of political, defense, security, trade, investment and socio-cultural relations such as culture, labor, sports and youth. As the result, both countries established the PhilippineIndonesia Plan of Action for 2014-2016 to arrange a roadmap, programs and timeline for cooperative initiatives. ${ }^{170}$ This agenda ever since, accelerate the both countries 20 years of negotiation on maritime border dispute. Both countries finally reached their agreement on the basis of international laws on maritime boundary delimitation. It was

\footnotetext{
169 Ziyad Falahi, "Memikirkan Kembali Arti Miliion Friends Zero Enemy Dalam Era Paradox of Plenty" 7 (n.d.).

170 Philippines, Indonesia Hold Successful Bilateral Talks. (n.d.). Retrieved from https://dfa.gov.ph/newsroom/dfa-

releasesupdate/2175-philippines-indonesia-holdsuccessful-bilateral-talks
}

the result of a rule-based negotiation to peacefully resolve maritime dispute between both countries.

The Philippines and Indonesia after all, have managed several meetings to reach an agreement on the maritime border dispute. On May 18 2014, both countries held the 8th Meeting of the JPWG-MOC in Jakarta. As the result, Foreign Secretary, Del Rosario and Foreign Minister Natalegawa signed the final agreement of delimitation of the EEZ boundary on May 23, 2014, in Malacañan Palace and mark as the end of the Philippines-Indonesia negotiations on maritime border dispute. ${ }^{171}$

The agreement, known as the Philippines' first maritime boundary treaty. Besides, for Indonesia, with its non block position in the international system, amicably and peaceful manner through negotiation, diplomacy and consistent with International law always help Indonesia to resolve its border dispute with its ten neighboring countries include the Philippines. Additionally, border diplomacy considered as top priorities in Indonesia's foreign policy.

The Philippines-Indonesia agreement on maritime border disputes thus provides clarity to both countries in order to carry out various activities in accordance with the sovereign rights they hold in the territory as contained in UNCLOS. ${ }^{172}$ A clearly defined EEZ boundary also provided $627 \mathrm{~nm}$ in length and composed of geodesic lines connecting eight points, as depicted in the figure below:

\footnotetext{
171 "Indonesia, Philippines to Finalize Overlapping Maritime Boundary Negotiations National - The Jakarta Post," accessed March 9, 2018 , http://www.thejakartapost.com/news/2016/07/02 /indonesia-philippines-to-finalize-overlappingmaritime-boundary-negotiations.html. ${ }^{172}$ Ibid
} 
Anak Agung Banyu Perwita,1Ircha Tri Meilisa2 | Co-Operative Maritime Diplomacy: The Resolution Of The Philippines-Indonesia Maritime Border Dispute (1994-2014)

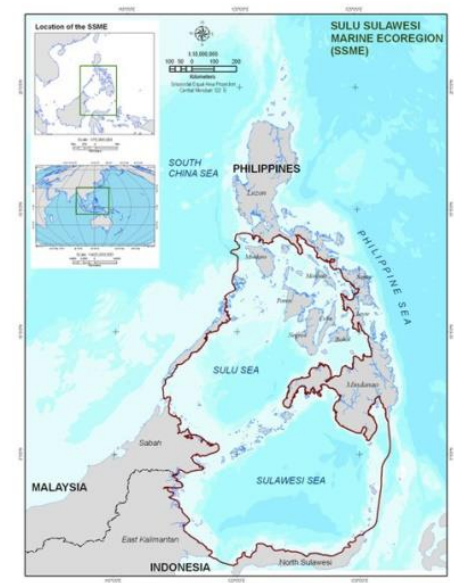

Figure II The Philippines Territorial Boundaries After Agreement 2014 (Source: ASEAN Briefing)

During the negotiation process, the Philippines and Indonesia have succeeded in implementi ng their maritime diplomacy. It proves that maritime diplomacy in the form of bilateral agreement through cooperation and coordination is necessary to maintain peace, stability, economic and social development in the bordering areas, either on land, maritime and airspace for which Indonesia is also committed regardless border dispute. It took almost two decades for both countries finally reach the final agreement of clearly defined territorial boundary.

\section{The Implementation of the Philippines Co-operative Maritime Diplomacy}

In the case of the PhilippinesIndonesia maritime border dispute, the author adopts the theory of maritime diplomacy to explain the implementation of the Philippines foreign policy strategy in managing its relations with other countries at the international level through the maritime domain.

In this regard, the Philippines signifies a co-operative maritime diplomacy, which well described as "soft power maritime diplomacy". In contrast with "hard power, maritime diplomacy" which use hard power asset, such as a gunboat, soft power diplomacy more into diplomatic mission. ${ }^{173}$ For instance, the Philippines as a claimant state in the South China Sea dispute, trying to build diplomatic influence and strengthen alliances against China especially with ASEAN countries through diplomatic mission.

During the 46th ASEAN Ministerial Meeting on June 30, 2013, Philippine Foreign Secretary Albert F. Del Rosario expressed his view of the increasing militarization of the South China Sea, to him, this poses a threat to regional stability. Therefore, in an effort to maintain peace and maritime stability, he tries to encourage all ASEAN member states to create a safe, stable and prosperous environment, such as the content of the following points of speech:

"If we are to live up to our
vision of a politically
cohesive, economically
integrated and people
oriented ASEAN Community,
then now, more than ever, is
the time to reaffirm our own
remarkable brand of unity
amidst diversity,"speech from
the Philippines Foreign
Affairs Secretary Albert F.
Del Rosario.

Since 2005, the Philippines has involved on bilateral security cooperation with Indonesia and Malaysia in the aftermath

\footnotetext{
${ }^{173}$ Miere, Christian Le. Maritime Diplomacy in the 21st Century (Drivers and Challenge).Routledge : 2014. Page 8

174 "Joint Communiqué 46th ASEAN Foreign Ministers' Meeting, Bandar Seri Begawan, Brunei Darussalam, 29-30 June 2013," http://www.asean.org/news

174 "Joint Communiqué 46th ASEAN Foreign Ministers' Meeting, Bandar Seri Begawan, Brunei Darussalam, 29-30 June 2013," http://www.asean.org/news
} 
Anak Agung Banyu Perwita,1Ircha Tri Meilisa2 | Co-Operative Maritime Diplomacy: The Resolution Of The Philippines-Indonesia Maritime Border Dispute (1994-2014)

9/11 tragedy to combat terrorist attack in the Celebes. ${ }^{175}$ Moreover, the Philippines also join CTI as regional cooperation on maritime security around the Coral Triangle to protect the marine environment and resources since 2007. Besides, both countries agreed to keep energize and support bilateral relations, by reviewing, updating and implementing agreement on trade, investment, shipping, and border trade agreement through the establishment of the Joint Commission on Bilateral Cooperation $(\mathrm{JCBC})$ in 2011. ${ }^{176}$ Moreover, the Philippines marine agencies willing to facilitate the process of analyzing potential areas for cooperation on fisheries and marine cooperation.

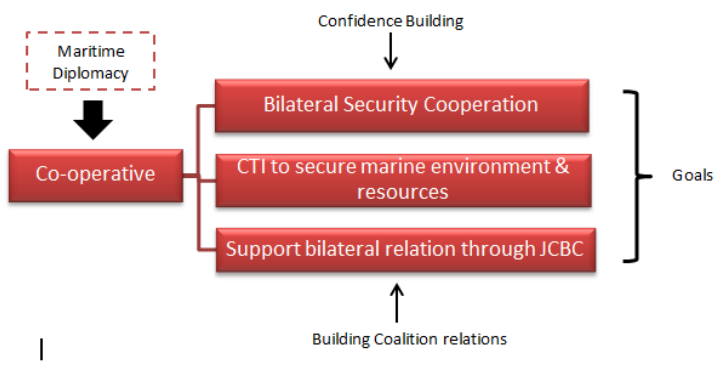

Figure IV Form of Co-operative Maritime

Diplomacy and Its Goals

Year by year, the Philippines and Indonesia keep showing their interest to immediately resolve their maritime border dispute since 1994, although progress remains slow, as aforementioned, both countries consistently involve in many

175 Robert Go, "Arroyo, Megawati Sign Deals and Discuss Security." The Straits Times. November 13, 2001.

176

http://www.officialgazette.gov.ph/2011/12/14/st atement-of-the-secretary-of-foreign-affairsduring-the-philippines-indonesia-jcbc-meetingdecember-14-2011/. (n.d.). Retrieved from http://www.officialgazette.gov.ph/2011 cooperation in maritime areas in accordance with the prevailing international law.

Co-operative maritime diplomacy can also be created to establish coalitions, support allies such as capacity building, training and harmonization of technique and confidence building among nations wary of one's naval power. ${ }^{177}$ Additionally, cooperative diplomacy in the form of joint maritime operations exercise not only to build capacity within less capable or knowledgeable navies, but also beneficial to reinforce a friendship and making the naval forces more compatible and strengthen bonds between allies or reassure potential rivals as to the non- threatening nature of one's navy.

In the concept of co-operative maritime diplomacy, all activities were designed not to deter or forcefully persuade others, but rather, in the implementation, cooperative maritime diplomacy engages the countries involved to share a common interest towards which they aim. In this regard, the Philippines seeks to make influences, coalition or alliances and confidence. $^{178}$

CTI is one of the implementation of the Philippine maritime diplomacy in the form of maritime security, by join CTI, the Philippines able to control and maintain its maritime area which bordered by others four countries include Indonesia. Within the CTI, both countries are able to strengthen their commitment to cooperate on maritime affairs and show a good example how to still cooperate on major initiative regardless maritime border dispute. Additionally, the CTI allowed both countries to share their common interest and achieve mutual goals. Both countries are very aware their people

\footnotetext{
${ }^{177}$ Miere, Christian Le. Maritime Diplomacy in the 21st Century (Drivers and Challenge).Routledge : 2014. Page 11

${ }^{178}$ Ibid
} 
Anak Agung Banyu Perwita,1Ircha Tri Meilisa2 | Co-Operative Maritime Diplomacy: The Resolution Of The Philippines-Indonesia Maritime Border Dispute (1994-2014)

live very much depends on maritime, and contributed to their economic growth. The CTI beyond just cooperation in maritime security, it is one of the Philippines approaches in solving its maritime border dispute with Indonesia., it is proven that after CTI both countries agreed to accelerate their negotiation on a maritime boundary without the use of force. Moreover, the Philippines and Indonesia JCBC served as the platform for both countries to show their commitment to bolster bilateral cooperation in various areas.

\section{Conclusion}

The implementation of the Philippines maritime diplomacy, specifically co-operative maritime diplomacy through several aspects include, the establishment of cooperation on behalf of common interest in economics, politics and security with the elaboration from the orientation and strategy of both countries' foreign policy toward maritime border dispute since 1994 when the UNCLOS came to power. In accordance to the UNCLOS, the Philippines and Indonesia realized, when it comes to the sovereignty issues such as a claim over land territory thus, a unilateral proclamation of maps will eventually be aligned with prevailing international law. The Philippines-Indonesia maritime border dispute is a sovereignty issue of land territory, hence, as both countries have ratified the UNCLOS, they pleased for a series of negotiation began in 1994.

Knowing the political and security concepts of the country, the Philippines has a similar orientation to its foreign policy since the Marcos administration, however, the Philippines' strategy and responses to maritime border disputes with Indonesia depend on the respective ruling presidents since 1994 when the Philippines lived under the leadership of Ramos until 1998, continuing through Estrada until 2001, then resumed by Arroyo for almost ten years before Aquino finally took his place. It should be underlined that every government has a degree of variability and interests that affect the Philippine foreign policy.

The implementation of the Philippine foreign policy strategy in the form of cooperative maritime diplomacy to resolve maritime border disputes with Indonesia shows how both countries are highly exposed to the longstanding value of friendship and show goodwill in settling maritime disputes peacefully. This is a significant contribution and a lesson for other countries still involved in the territorial dispute of reasonable efforts to achieve a stable and peaceful regional society, taking into account the interests of the countries concerned and in compliance with prevailing international law.

The Philippines and Indonesia negotiation of the maritime border dispute to delimit their EEZs has embodied the results in an agreement. The negotiation took 20 years to finally achieve clearly defined territory from the Celebes to Mindanao sea, however, during the long standing negotiation, both countries have shown each capability and wisdom to achieve peace and stability in the region through enhanced cooperation. In spite of the fact that they have not yet established any agreement of maritime boundaries before 2014, both countries were able to keep their healthy relations and cooperate in a major initiative on maritime issues such as bilateral security cooperation in the Celebes sea and CTI, hence, it showed that this maritime border dispute between the Philippines-Indonesia is the good example of how to resolve sovereignty issues without the use of force.

The Philippines-Indonesia maritime border dispute eventually gains momentum when the Philippines was led by President Arroyo since 2001. During her administration, Arroyo projected many 
Anak Agung Banyu Perwita,1Ircha Tri Meilisa2 | Co-Operative Maritime Diplomacy: The Resolution Of The Philippines-Indonesia Maritime Border Dispute (1994-2014)

agendas that fortunately ease its negotiation on maritime border dispute with Indonesia, for instance, in 2005 as a response towards security threats such as terrorist and piracy, Arroyo initiated bilateral security cooperation in the Celebes sea which some of the parts also claimed by Indonesia, and in 2007 to join CTI-CFF. Within these cooperations, the two countries were able to maintain their relations regardless boundary issues. Additionally, when the Philippines faced the difficulty of Chinese assertiveness in the South China Sea dispute, Arroyo formulated foreign policy strategy to align the Philippines maritime law in accordance to the UNCLOS, ever since the Philippines' territorial boundary finally recognized in the International system as it used the same prevailing international with other state parties in the UNCLOS, particularly Indonesia.

These important events were produced during the Arroyo's administration. Fortunately, it was sustained well by Aquino's administration. Aquino considered the relation with Indonesia is essential not only in the field of security, but also fisheries, tourism, trade, investment and etc. Thus, Aquino directed the foreign policy to settle a peaceful resolution of the maritime border dispute with Indonesia. Since he led the Philippines in 2010, a number of major initiatives and cooperation were made, specifically who contributed a lot towards the resolution of the maritime border dispute which is JCBC in 2011 and 2014. Ever since, Aquino and his counterpart: Indonesia's President SBY committed to show their greater attention to extend and strengthen cooperation in so many fields, both agree by finishing their long standing negotiation on boundary will be marked as their first and important step to further cooperate in major areas. 
Anak Agung Banyu Perwita,1Ircha Tri Meilisa2 | Co-Operative Maritime Diplomacy: The Resolution Of The Philippines-Indonesia Maritime Border Dispute (1994-2014)

\section{REFERENCES}

A Principled Philippine Foreign Policy Under the Aquino Administration. (n.d.). Retrieved from https://dfa.gov.ph/index.php/speeches/8517-a-principled-philippine-foreign-policy-underthe-aquino-administration

Anwar, D. F. (2014, February 4). Indonesia's foreign relations: policy shaped by the ideal of 'dynamic equilibrium'. Retrieved from http://www.eastasiaforum.org

Arroyo, G. M. (2004). A Compilation of selected presidential speeches of Her Excellency President Gloria Macapagal-Arroyo. Office of the Press Secretary, Bureau of Communications Services.

Asean nations fail to reach agreement on South China Sea. (2012, July 13). Retrieved from http://www.bbc.com/news/world-asia-18825148

Bautista, L. B. (2009). The Philippines Treaty Limits and Territorial Waters Claim In International Law. Social Science Diliman, 5(1-2), 107-127.

Bautista, L. B. (2008). The Historical Context and Legal Basis of the Philippine Treaty Limits. Asian Pacific Law \& Policy Journal, 10(1).

Breadsher, K. (2014, February 4). Philippine Leader Sounds Alarm to China. Retrieved from https://www.nytimes.com

Briefer: Diplomatic relations between the Philippines and Indonesia | GOVPH. (n.d.). Retrieved from http://www.officialgazette.gov.ph/diplomatic-relations/ph-id/

Buszynski, L., \& Roberts, C. B. (2015). The South China Sea Maritime Dispute: Political, Legal and Regional Perspective. New York: Routledge.

Coral Triangle Initiative on Coral Reefs, Fisheries and Food Security, issuing body. (2009). Regional plan of action: Coral Triangle Initiative on Coral Reefs, Fisheries and Food Security (CTI-CFF).

Cukwurah, A. O. (1967). The settlement of boundary disputes in international law (1st ed.). Manchester: Manchester U.P

De Castro, R. C. (2012). The Aquino Administration's 2011 Decision to Shift Philippine Defense Policy From Internal Security to Territorial Defense: The Impact of the South China Sea Dispute. The Korean Journal of Defense Analysis, 24(1), 67-87.

Ellis, J., Moore, J. N., Nordquist, M. H., \& University of Virginia. (2012). Maritime border diplomacy. Leiden: Martinus Nijhoff Publishers.

Fidel V. Ramos, Sixth State of the Nation Address. (1997, July 28). Retrieved from http://www.officialgazette.gov.ph

Febrica, S. (2017). Maritime security and Indonesia: Cooperation, interests and strategies. Routledge.

Food and Agriculture Organization of the United Nations. (2014). The state of world fisheries and aquaculture: 2004. Rome: Author.

Go, R. (2001, November 13). Arroyo, Megawati Sign Deals and Discuss Security. The Straits Times.

Indonesia, Philippines Reach Four-Point Agreement. (2005, June 20). BBC.

Keynote Speech by H.E. Susilo Bambang Yudhoyono President Republic of Indonesia At the ASEAN Forum: Rethinking ASEAN Towards the ASEAN Community 2015 Jakarta, 7 August 2007. (2007). Retrieved from ASEAN website: http://asean.org 
Anak Agung Banyu Perwita,1Ircha Tri Meilisa2 | Co-Operative Maritime Diplomacy: The Resolution Of The Philippines-Indonesia Maritime Border Dispute (1994-2014)

Kreuzer, P. (2016). A Comparison of Malaysian and Philippine Responses to China in the South China Sea. The Chinese Journal of International Politics, 9(3), 239-276. doi:10.1093/cjip/pow008

Mahbubani, K., \& Sng, J. (2017). The ASEAN miracle: A catalyst for peace. Singapore: The Ridge Books.

Miere, C. L. (2015). Maritime diplomacy in the 21st century. Place of publication not identified: Routledge.

National Coral Triangle Initiative (Philippines). Coordinating Committee. (2013). State of the Coral Triangle report, Philippines, 2012. Retrieved from www.coraltriangleinitiative.net

Nye, J. S. (2011). The Future of Power. New York: Public Affairs.

Pattiradjawane, R. L., \& Soebagjo, N. (2016). Establishing Maritime Diplomacy in Southeast Asia: Balancing ASEAN Regional Interest in the Rise of Competing Great Power Rivalry. Global Journal of Human Social Science, 16(3).

Pattugalan, G. R. (1999). Philippine Foreign Policy Under the Ramos Administration. Philippine Journal of Third World Studies, 14(3), 138.

Patuzi, D. (2015). The Concept of the Exclusive Economic Zone. Academic Journal of Business, Administration, Law and Social Sciences, 1(1), 150.

Pengantar Soal Perkembangan Politik Luar Negeri Terutama Kerjasama Negara-Negara ASEAN. (n.d.). Kementerian Kelautan dan Perikanan Republik Indonesia.

Philippines. Cabinet Committee on Maritime and Ocean Affairs. (1994). National marine policy. Manila: Foreign Service Institute.

Philippines, Indonesia Hold Successful Bilateral Talks. (n.d.). Retrieved from https://dfa.gov.ph/newsroom/dfa-releasesupdate/2175-philippines-indonesia-holdsuccessful-bilateral-talks

Philippines and Indonesia Sign Agreement on EEZ Boundary. (2014). Retrieved from https://www.dfa.gov.ph

Philippines. President (1986-1992 : Aquino). (1989). The state of the nation address: President Corazon C. Aquino : Congress of the Philippines opening of the third regular session, 24 July 1989. Retrieved from Office of the Press Secretary, Philippine Information Agency website: http://www.officialgazette.gov.ph

Purwanto, H., \& Mangku, D. G. (2016). Legal Instrument of the Republic of Indonesia on Border Management Using the Perspective of Archipelagic State. International Journal of Business, Economics and Law, 11(4).

Pusat Data, Statistik, dan Informasi Kementrian Kelautan dan Perikanan, Informasi Kelautan dan Perikanan. (2016). Retrieved from Kementrian Kelautan dan Perikanan website: http://statistik.kkp.go.id/sidatik-dev/Publikasi/src/informasikpjanuari2016.pdf

Tayfur, M. F. (1994). Main Approaches to the Study of Foreign Policy. METU Studies in Development, 21(1), 113-141.

Tayfur, M. F. (2003). Semiperipheral Development and Foreign Policy: The Cases of Greece and Spain. Ashgate Pub Ltd.

The Philippines Indonesia to Hold 6th on Joint Commission on Bilateral Relations. (n.d.). Retrieved from https://dfa.gov.ph/newsroom/dfa-releasesupdate/2175-philippinesindonesia-hold-successful-bilateral-talks 
Anak Agung Banyu Perwita,1Ircha Tri Meilisa2 | Co-Operative Maritime Diplomacy: The Resolution Of The Philippines-Indonesia Maritime Border Dispute (1994-2014)

The Philippines' Relationship With ASEAN. (2017, March 22). Retrieved from https://www.aseanbriefing.com

The World Bank. (n.d.). Philippines Coastal and Marine Resources: An Introduction. Retrieved from http://siteresources.worldbank.org

Turcsányi, R. Q. (2017). The Puzzle of Chinese Assertiveness. Global Power Shift, 1-29. doi:10.1007/978-3-319-67648-7_1

UNCLOS. (1982, December 10). Law of the Sea. Retrieved from http://treaties.un.org

United Nations Convention on the Law of the Sea 1982.

Victor, J., \& Gonzaga, C. (1997). UNCLOS and the Philippines Territorial Sea: Problems,Perspectives and Options. Ateneo Law Journal, 13(1), 15. 